\title{
Nanotechnology: the word is new but the concept is old. An overview of the science and technology in food and food products at the nanoscale level
}

\author{
BRIAN C. BRYKSA ${ }^{a}$ AND RICKEY Y. YADA ${ }^{a}, b^{*}$ \\ ${ }^{\text {a }}$ Department of Food Science, University of Guelph, Guelph, Ontario, Canada N1G 2W1 \\ b Advanced Foods and Materials Canada, Guelph, Ontario, Canada \\ ${ }^{*}$ Corresponding author \\ ryada@uoguelph.ca \\ TEL: +519-824-4120 EXT. 58915 \\ FAX: $+519-824-6631$
}

Received: 13 January 2012; Published online: 18 October 2012

Invited paper from the $2^{\text {nd }}$ International ISEKI_Food Conference 2011

\begin{abstract}
Food scientists and technologists are actively engaged in examining and developing nanotechnologies for applications such as novel functional ingredients and nutrient delivery systems, safety testing, packaging, and authenticity/authentication at an ever-increasing pace. However, before these new products/technologies are commercialised, rigorous safety testing and risk/benefit analysis are required to ensure that public and environmental concerns are addressed. This review provides an overview of food nanoscience and technology including a brief history, education, definitions pertaining to policy and regulation, and applications. The most recent findings and advances are emphasised, focussing on bioactives' delivery. In addition, proposed directions in the area of nano-based targeting of pathogens for food safety as well as medical foods are discussed. As food nanoscience and technology has been extenisvely reviewed in recent years, specific case examples will be limited to those reported within the past year.
\end{abstract}

Keywords: Nanotechnology; Nanoscience; Functionality; Safety; Controlled release; Health; Public perception

\section{Introduction}

The 'nano' realm cannot be easily visualised directly, unlike for instance living cell components or inorganic/organic crystal structures, and only larger nanoscale objects in the hundreds of $\mathrm{nm}$ can be visualised using the most powerful microscope technology (van Putten et al., 2011). It has been postulated that the science of 'nano' technologies requires, more than any other science, the visualisation and creation of a narrative for describing the relevant phenomena. In other words, 'nano' advances represent a change in per- ception of reality from a visual culture to one based on sensing and connectivity (Gimzewski \& Vesna, 2003). Nanotechnology itself is not new: Although the purposeful engineering of technologies on the billionth of a metre length scale under the banner 'nano' is a relatively recent endeavour, the use and manipulation of materials that were observed to behave uniquely is quite old. For example, 1500 years ago, Romans made the Lycurgus Cup with dichroic glass containing colloidal gold and silver, giving a green appearance when lit from the outside and red when lit from within ("National Nanotechnology Insti- 
tute," 2011). In terms of science-based modern engineering, the beginning of 'nano' was just over 50 years ago, with a talk given by Richard Feynman in which he observed, 'Atoms on a small scale behave like nothing on a large scale, for they satisfy the laws of quantum mechanics. So, as we go down and fiddle around with the atoms down there, we are working with different laws, and we can expect to do different things' (Feynman, 1960). The actual term 'nanotechnology' was first published several years later in reference to engineering novel materials via processes governed by single atoms or molecules (Taniguchi, 1974).

At present, there are over 1300 identified 'nano' products, a number that has more than quintupled over the past 5 years ("Project on Emerging Nanotechnologies," 2011), which are produced by hundreds of different companies located in many countries, with the United States having the greatest number (Claonadh et al., 2011). No longer is the educational field of nanotechnology simply a subsection of physics curricula, but there are now dedicated nanotechnology undergraduate and graduate degrees offered at various universities globally (Sweeney, A.E. \& Seal, S, 2008). Additionally, educational tools for children are also available, e.g., Nanooze; (nanooze.org) and Nanowerk (nanowerk.com). Some scientific peer-reviewed journals are dedicated exclusively to nanoscience and technology: Nanotechnology, Nano Letters, International Journal of Nanosciences, International Journal of Nanotechnology and Small.

Globally, the food and beverage sector in 2008 was valued at $\$ 5.7$ trillion USD according to New Zealand Trade \& Enterprise, with several nations spending hundreds of billions of dollars each year on their own. For example, the value of the food and beverage industry in Germany was $\$ 200$ billion USD in 2010 (Lindel, 2011), China was $\$ 250$ billion USD in 2007, and the United States was just under $\$ 1$ trillion USD in 2010. Arguably, the newest and most exciting market sub-sector for the food industry is nanotechnology with its unique promises and widespread uses from farm to dinner plate. Nanoparticles have the potential to revolutionise foods in terms of production, processing, packaging, and transportation and storage (Lin, Li, Song, \& Wu, 2011b).
For example, some metal nanoparticles are potent antimicrobial agents that can kill foodborne pathogens; nanosensors offer new ways to detect pathogens (Ravindranath, Wang, \& Irudayaraj, 2011) as well as other microbes, gases or chemical contaminants in complex food matrices (Duncan, 2011a); and nanoencapsulation can facilitate nutritional fortification of foods with nutrients (Srinivas et al., 2010) and nutraceuticals (Sessa, Tsao, Liu, Ferrari, \& Donsi, 2011). Existing food-related products currently on the market include cooking instruments (e.g., nonstick coating for glass bakeware), food ingredients/additives (e.g., phytosterol-containing micelles in canola oil for lowering intestinal cholesterol absorption), and supplements (e.g., solubilised turmeric bioactives) ("Project on Emerging Nanotechnologies," 2011).

It has become increasingly difficult to capture all the scientific advancements due to the explosion of food nanotechnology research and development. As observed recently, the sheer number of developments and applications that fall under the nanotech rubric can be overwhelming (Brehm-Stecher, B.,F. 2009). With respect to reviews on nanotechnology in general, recent searches limited for publications within the past two years using two popular scientific search portals produced hundreds of review articles. Likewise for food nanoscience and technology, many recent reviews have been written on various topics. To aid food scientists navigate these, we have summarised various recent food nanoscience and technology reviews (see Table 1 ). In the past year alone, food-related reviews have been published on packaging (Bradley, Castle, \& Chaudhry, 2011; Duncan, 2011b), nanotechnology safety (Card, Jonaitis, Tafazoli, \& Magnuson, 2011; Magnuson \& Bouwmeester, 2011; Magnuson, Jonaitis, \& Card, 2011; Teow, Asharani, Hande, \& Valiyaveettil, 2011), detection of nanomaterials in food (Blasco \& Picó, 2011), drug delivery using food material-based nanoencapsulation (Elzoghby, El-Fotoh, \& Elgindy, 2011; Prabaharan, 2011), ingredient nanoencapsulation (Fathi, Mozafari, \& Mohebbi, 2012), engineered nanomaterials (Morris, 2011), communication (Duncan, 2011a), starch nanocrystals, (Lin, Huang, Chang, Anderson, \& Yu, 2011a) as well as general reviews (Neethirajan \& Jayas, 2011; Rashidi 
Table 1: Food-related reviews on nanoscience and technology over the past four years.

\begin{tabular}{|c|c|c|c|}
\hline REFERENCE & Topic & Title & Year \\
\hline (Sozer \& Kokini, 2009) & General & $\begin{array}{l}\text { Nanotechnology and its applications in the food } \\
\text { sector }\end{array}$ & 2009 \\
\hline (Rashidi \& Khosravi-Darani, 2011) & General & $\begin{array}{l}\text { The Applications of Nanotechnology in Food In- } \\
\text { dustry }\end{array}$ & 2011 \\
\hline (Neethirajan \& Jayas, 2011) & General & $\begin{array}{l}\text { Nanotechnology for the Food and Bioprocessing } \\
\text { Industries }\end{array}$ & 2011 \\
\hline (Duncan, 2011b) & Packaging & $\begin{array}{l}\text { Applications of nanotechnology in food packaging } \\
\text { and food safety: Barrier materials, antimicrobials } \\
\text { and sensors }\end{array}$ & 2011 \\
\hline (Srinivas et al., 2010) & Nutrition & $\begin{array}{l}\text { Nanotechnology Research: Applications in Nutri- } \\
\text { tional Sciences }\end{array}$ & 2010 \\
\hline (Bouwmeester et al., 2009) & Safety & $\begin{array}{l}\text { Review of health safety aspects of nanotechnolo- } \\
\text { gies in food production }\end{array}$ & 2009 \\
\hline (Card et al., 2011) & Safety & $\begin{array}{l}\text { An appraisal of the published literature on the } \\
\text { safety and toxicity of food-related nanomaterials }\end{array}$ & 2011 \\
\hline (Magnuson et al., 2011) & Safety & $\begin{array}{l}\text { Occurrence, Use, and Safety of Food-Related } \\
\text { Nanomaterials }\end{array}$ & 2011 \\
\hline (Wijnhoven et al., 2009) & Safety - nano-silver & $\begin{array}{l}\text { Nano-silver }- \text { a review of available data and } \\
\text { knowledge gaps in human and environmental risk } \\
\text { assessment }\end{array}$ & 2009 \\
\hline (Augustin \& Hemar, 2009) & Ingredient encapsulation & $\begin{array}{l}\text { Nano- and micro-structured assemblies for encap- } \\
\text { sulation of food ingredients }\end{array}$ & 2009 \\
\hline (Duncan, 2011a) & Communication & $\begin{array}{l}\text { The communication challenges presented by } \\
\text { nanofoods }\end{array}$ & 2011 \\
\hline (Bradley et al., 2011) & Packaging & $\begin{array}{l}\text { Applications of nanomaterials in food packaging } \\
\text { with a consideration of opportunities for develop- } \\
\text { ing countries }\end{array}$ & 2011 \\
\hline (Smolander \& Chaudhry, 2010) & Packaging & Nanotechnologies in Food Packaging & 2010 \\
\hline ((Magnuson \& Bouwmeester, 2011) & Safety & Toxicology of Nanomaterials in Food & 2011 \\
\hline (Lin et al., 2011b) & Starch nanocrystals & $\begin{array}{l}\text { Preparation, modification, and application of } \\
\text { starch nanocrystals in nanomaterials: a review }\end{array}$ & 2011 \\
\hline (Teow et al., 2011) & Safety & $\begin{array}{l}\text { Health impact and safety of engineered nanoma- } \\
\text { terials }\end{array}$ & 2011 \\
\hline (Prabaharan, 2011) & $\begin{array}{l}\text { Guar gum for drug deliv- } \\
\text { ery }\end{array}$ & $\begin{array}{l}\text { Prospective of guar gum and its derivatives as } \\
\text { controlled drug delivery systems }\end{array}$ & 2011 \\
\hline (Elzoghby et al., 2011) & Caseins for drug delivery & $\begin{array}{l}\text { Casein-based formulations as promising con- } \\
\text { trolled release drug delivery systems }\end{array}$ & 2011 \\
\hline (Kanwar, Long, \& Kanwar, 2011) & $\begin{array}{l}\text { Cyclodextrins for drug } \\
\text { delivery }\end{array}$ & $\begin{array}{l}\text { The use of cyclodextrins nanoparticles for oral de- } \\
\text { livery }\end{array}$ & 2011 \\
\hline (Morris, 2011) & $\begin{array}{l}\text { Engineered nanomateri- } \\
\text { als }\end{array}$ & $\begin{array}{l}\text { Emerging roles of engineered nanomaterials in the } \\
\text { food industry }\end{array}$ & 2011 \\
\hline (Blasco \& Picó, 2011) & $\begin{array}{l}\text { Detection of nanomate- } \\
\text { rials }\end{array}$ & Determining nanomaterials in food & 2011 \\
\hline (Fathi et al., 2012) & Nanoencapsulation & $\begin{array}{l}\text { Nanoencapsulation of food ingredients using lipid } \\
\text { based delivery systems }\end{array}$ & 2011 \\
\hline (Lagaron \& Lopez-Rubio, 2011) & Nanomaterials & $\begin{array}{l}\text { Nanotechnology for bioplastics: opportunities, } \\
\text { challenges and strategies }\end{array}$ & \\
\hline
\end{tabular}

\& Khosravi-Darani, 2011).

\section{Definitions and regulation}

Length scale and uniqueness/novelty associated with the nanoscale nature of a given material are the factors generally used to define whether a material is 'nano'. Nanotechnology is the application of scientific knowledge to manipulate and control matter in the nanoscale range to make use of size- and structure-dependent properties and phenomena that are distinct from those at

smaller or larger scales (Roco, 2011). The invocation of the $1 \mathrm{~nm}$ - $100 \mathrm{~nm}$ dimension scale is ubiquitous; it is used by the National Nanotechnology Initiative (U.S.A.); Environmental Protection Agency (U.S.A.); European Scientific Committee on Consumer Products; European Commission (EC); Health Canada; International Organization for Standardization (ISO); Organization for Economic Cooperation and Development's Working Party on Nanotechnology and Working Party on Manufactured Nanomaterials; National Cancer Institute (U.S.A.); and Amer- 
ican National Standards Institute. Outside of governmental agencies, ISO offers a process for identifying, evaluating, addressing, making decisions about, and communicating the potential risks of developing and using manufactured nanomaterials ("The International Organization for Standardization," 2011).

In terms of regulation in the United States (Food and Drug Administration; FDA) and Europe (European Food Safety Authority; EFSA), nanomaterial definitions are similar, however, those used for official regulatory purposes differ. Similar to, and consistent with Feynman's original description (Feynman, 1960), the FDA definition is that nanotechnology is the understanding and control of matter at dimensions between approximately $1 \mathrm{~nm}$ to $100 \mathrm{~nm}$ where unique phenomena enable novel applications ("U.S. Food and Drug Administration," 2011a). This FDA definition is not, however, a formal definition of 'nanotechnology,' 'nanomaterial,' 'nanoscale,' or related terms. When considering whether FDAregulated products including dietary ingredients contain nanomaterials and/or involve the application of nanotechnology, the FDA asks whether an engineered material or end product (i) has at least one dimension in the nanoscale range, or (ii) exhibits properties or phenomena, including physical or chemical properties or biological effects, that are attributable to its dimension(s), even if these dimensions fall outside the nanoscale range, up to one micrometer ("U.S. Food and Drug Administration," 2011b). In Canada, as per the Policy Statement on Health Canada's Working Definition for Nanomaterial, the risks and benefits of a nanomaterial are assessed by Health Canada. Assessments are based upon five types of information (when relevant): (i) Intended use, function and purpose of the nanomaterial, and information regarding any end product in which it will be used; (ii) Manufacturing methods; (iii) Characteristics, and physical chemical properties of the nanomaterial; (iv) Toxicological, eco-toxicological, metabolism and environmental fate data; and (v) Risk assessment and risk management strategies ("Health Canada," 2011a).

As of 2009, the EC officially defined nanotechnology as the understanding and control of matter and processes at the nanoscale, typically, but not exclusively, below 100 nanometres in one or more dimensions, where the onset of sizedependent phenomena can emerge and enable novel applications ("Commission of the European Communities," 2009). Recently, however, the EC altered this definition in consideration of the 2010 conclusion by the Scientific Committee on Emerging and Newly Identified Health Risks that there is no identified specific size at which a specific property changes or appears, or a specific property that is introduced or changed with size ("Scientific Committee on Emerging and Newly Identified Health Risks (SCENIHR)," 2010). The new EC definition is now: "Nanomaterial' means a natural, incidental or manufactured material containing particles, in an unbound state or as an aggregate or as an agglomerate and where, for $50 \%$ or more of the particles in the number size distribution, one or more external dimensions is in the size range $1 \mathrm{~nm}-100$ $\mathrm{nm}$ " and "...some materials with a size smaller than $1 \mathrm{~nm}$ or greater than $100 \mathrm{~nm} . . . "$ ("The European Commission," 2011). Consequently, this new focus on size alone marks an important shift in European nano regulation from that in place in North America, as well as from canonical nanotechnology definitions.

\section{$3 \quad$ Safety and Fear}

The potential toxicities/safety and biological/health impacts of food-related nanomaterials have been extensively reviewed (Magnuson \& Bouwmeester, 2011; Magnuson et al., 2011; Teow et al., 2011). The six principal categories of nanomaterials are (i) organic polymers/polymeric micelles/dendrimers, (ii) organic-inorganic nanocomposites, (iii) carbon nanotubes/fullerene, (iv) liposomes, (v) biologicals (proteins, lipids, carbohydrates), and (vi) inorganics ( $\mathrm{Ag}, \mathrm{Au}, \mathrm{Pt}, \mathrm{Fe}, \mathrm{TiO}_{2}, \mathrm{CaCO}_{3}$, quantum dots, silica) (Teow et al., 2011). Environmental sources, plant and animal production, release from packaging materials, and food processing aids or equipment surface coatings are all potential sources of unintentional nanomaterial contamination in foods (Magnuson et al., 2011). Analysis of nanomaterials in foods is still in its infancy, although some methods exist that 
are proven to be effective in this regard (Blasco \& Picó, 2011). Only a limited number of repeated oral dose exposure studies have been carried out (Magnuson \& Bouwmeester, 2011), and presumably this relates to the dearth of methods for quantifying engineered nanoparticles in foods (Blasco \& Picó, 2011). Card et al. (2011) recently assessed the current state of knowledge regarding the toxicity of orally administered food-related nanomaterials and concluded that the majority of the 30 cited publications lacked certain key elements of standard experimental design (Card et al., 2011). An important consideration for quantification and characterisation of nanoparticles in a food system is to confirm that the specific material in question behaves in the test conditions in a manner consistent with the food system (Magnuson et al., 2011). Furthermore, evaluation of the equivalence of different methods for measuring given nanomaterial metrics is ongoing, and a lack of testing standardisation exists at present (Magnuson \& Bouwmeester, 2011). In general, nanomaterial characteristics that influence/determine its desirable and/or undesirable biological effects (i.e., deposition, distribution, clearance, biological responses) are size, shape, structure, surface charge and reactivity (Magnuson et al., 2011).

Food scientists, industrialists and regulatory bodies are duly concerned about apparent public perceptions of dangers associated with the use of nanotechnologies in foods. In May 2011, a summary of the results of a Canadian governmentpublic interaction regarding nanotechnology was reported ("Health Canada," 2011b). The Interim Policy Statement on Health Canada's Working Definition for Nanomaterials was posted online in March 2010 for a period of six months to provide an opportunity for stakeholders with a diverse range of interests to comment. Additionally, over 3,000 individuals and organizations (industry associations, public interest groups, government bodies, public health associations and regulatory authorities) were directly contacted. Health Canada subsequently received a total of just 29 submissions, only two of which were food organisations (a food ingredient producer and an industry organization, the Food \& Consumer Products of Canada) ("Health Canada," 2011b). In a similar recent outcome by the European Food
Safety Authority, a public consultation period of 6 weeks on potential risks of food nanotechnologies resulted in comments from just 35 parties (including government organisations) ("The European Food Safety Authority," 2011), a relatively modest number considering the enormous population and multiple political subdivisions within Europe. Thus, the food scientists and technologists should be weary of over-estimating or over-interpreting public perceptions of nanotechnology risks, and furthermore, regulatory bodies should not uniformly assume a high degree of concern among the public. Lastly, the belief that policy making processes should include public engagement is scientifically unclear in terms of what types/formats of such engagements produce useful information and insights for scientists and policy makers (PytlikZillig \& Tomkins, 2011).

A specific example of the influence and implications of perceived public fear is exemplified in a recently published patent for a microcapsule design (Lakkis, J.M. \& García, A.J.M. 2011) in which one of the disclosed similarities to previous inventions involved a stable nano-size calcium capsule design with enhanced stability and bioavailability (Flendrig, L.M. and Marshman, C.E. and Velikov, K.P. \& Winter, I. 2009). The latter nano-technology was acknowledged to be technically advantaged over the microcapsule (Lakkis, J.M. \& García, A.J.M. 2011), however, they cited two limitations of the nanoparticle, one of which is 'the food industry's recent concern about regulatory implications of using nanoparticles and/or disclosing their incorporation into food formulations' (Lakkis, J.M. \& García, A.J.M. 2011). The microcapsule invention in question protects, sequesters and delivers edible molecules (minerals, flavors, fragrances or other biological or inorganic actives) within an edible oil (Lakkis, J.M. \& García, A.J.M. 2011). This assembly can be incorporated at high concentrations while reducing negative impact on the functional and sensory aspects of certain food products (e.g., precipitation, flocculation, sedimentation and gritty mouth-feel resulting from calcium fortification), including jelly-type deserts and fruit-in-the-bottom yogurt (Lakkis, J.M. \& García, A.J.M. 2011). The citation of nano-fear as a disadvantage of another similar (nano) en- 
capsulation system (represented by Unilever two years previous) is one example of the impact on nanotechnologies arising from a perception of public fear, legitimate or not, among some scientists.

\section{Use of 'food'-derived compounds as structural components in oral/edible drug/bioactive delivery}

Compared to repeated injection, oral administration of drugs is more convenient, comfortable and easy for self-medication, and it suppresses risk of disease transmission, reduces cost and increases patient compliance (Plapied, Duhem, des Rieux, \& Préat, 2011). The purpose of controlled drug targeting is to minimise the risk-to-benefit ratio, hence the goals of designing and developing novel drug delivery systems are (1) precision for delivery target site, (2) safe drug delivery to its target site(s), and (3) maximised therapeutic effect through controlling delivery timing and release rate (Mishra, Patel, \& Tiwari, 2010). Compounds capable of forming inclusion complexes with biologically active agents can serve as vehicles for pharmaceutical, food, cosmetic and other applications (Kurkov, Ukhatskaya, \& Loftsson, 2011). As natural biomaterials, polysaccharides are highly stable, safe, non-toxic, hydrophilic, biodegradable, abundantly available, and have a low cost in their processing (Prabaharan, 2011). Lipids also serve as carriers of bioactives, and have been recently reviewed (Fathi et al., 2012). For example, tea polyphenols which are oxidised via exposure to oxygen and light were stabilised by the use of nanoliposomes $(\mathrm{Lu}, \mathrm{Li}, \&$ Jiang, 2011). In addition, protein-based systems have been studied for delivering drugs, nutrients, bioactive peptides and probiotic organisms, including gelatin, collagen, casein, albumin and whey protein (Elzoghby et al., 2011). The following are recent examples of food-related nanoparticles in the delivery of bioactives/drugs with potential for incorporation into food systems.

\subsection{Chitosan}

Chitosan, derived from chitin, the structural carbohydrate of crustaceans and fungi, is a cationic polysaccharide composed of randomly distributed $\beta$-(1-4)-linked D-glucosamine and Nacetyl-D-glucosamine. It is biocompatible, nontoxic and mucoadhesive (Plapied et al., 2011), however, the use of chitosan nanoparticles for oral peptide and protein delivery is limited by the dissolution of the polymer matrix at the low $\mathrm{pH}$ of the stomach (Makhlof, Tozuka, \& Takeuchi, 2011). Makhlof et al. (2011) recently sought to develop acid-stable chitosan nanoparticles capable of delivering entrapped insulin, a peptide drug, to the mucosal surface of the small intestine. Poor absorption through the intestinal membrane is a problem for peptide and protein drugs due to intrinsic properties such as high molecular weight and hydrophilicity, as well as susceptibility to enzymatic degradation in the gut (Makhlof et al., 2011). Entrapment of peptide drugs in micro/nanoparticle carriers protects them against the harsh environment of the gastrointestinal tract until they are absorbed or released (Makhlof et al., 2011). Modification of the chitosan polymer using hydroxypropyl methylcellulose phthalate cross linking resulted in acid stability, improved mucoadhesion, deeper penetration through the small intestine, and enhanced in vivo peroral delivery of insulin thereby offering the potential to control the release rate, and facilitate transport, of peptide drugs across the intestinal barrier (Makhlof et al., 2011). Also recently, chitosan nanoparticles were shown to be useful in the delivery of a bioactive plant extract (Bhatia, Shard, Chopra, \& Mishra, 2011). The immunomodulatory leaf extract of Ber ( $Z i z i$ phus mauritiana) was encapsulated such that the extract bioactivity was improved (Bhatia et al., 2011). Similarly, $\alpha$-tocopherol delivery and uptake was improved by incorporating chitosan into poly-lactic/poly-glycolic acid (PLGA) nanoparticles, shown both in vitro and ex vivo (Murugeshu, Astete, Leonardi, Morgan, \& Sabliov, 2011).

Chitosan-containing nanoparticle technology was recently the focus of a newly approved patent for the stabilisation and incorporation of oil nutraceuticals into foods (Kim, Kim, Cho, Choi, \& 
Choi, 2011). The system in question comprises both a nano emulsion that stabilises, as well as increases bioavailability of plant essential oil and water soluble biopolymer nano particles capable of imparting stability and increased solubility in the nano emulsion (Kim et al., 2011). In addition to stabilisation, the nano emulsion claims to maximise internal resorption using edible materials, and reduce the strong intestinal effect and flavour of functional oil components (Kim et al., 2011).

\subsection{Guar gum}

Guar gum and its derivatives have also been employed as controlled drug delivery systems, and developments in this area have been summarised recently (Prabaharan, 2011). Guar gum and its derivatives have been applied as colon specific, antihypertensive, protein, as well as transdermal drug delivery systems. As with cyclodextrins, different methods of preparation, properties and applications of chemically modified guar gum have been designed for the association and delivery of drugs in various scenarios (Prabaharan, 2011). Guar gum (Yan, Chang, Zheng, \& Ma, 2012) as well as starch (Yan, Chang, \& Zheng, 2011) were recently used to improve the solubility of carbon nanotubes, whose wide spectra of uses include efficient adsorption for removing many kinds of organic and inorganic contaminants, accomplished via their grafting to the exterior of the nanotubes. Furthermore, the guar gum hydroxyl groups facilitated association of subsequently added iron oxide nanoparticles (Yan et al., 2012). The resultant magnetic complex possessed the properties of adsorption capacity and magnetic separation, and therefore, can be used as magnetic adsorbents to remove contaminants from aqueous solutions (Yan et al., 2012).

\subsection{Cyclodextrins}

A category of inclusion complex-forming compounds that has been approved for usage in both pharmaceutical formulations and food products is that of the cyclodextrins which have received continuous and increasing interest from both academic and industrial scientists (Kurkov et al., 2011). Recently, the ability of bioadhesive cyclodextrin-poly(anhydride) nanoparticles as carriers for the oral delivery of atovaquone was characterised. This drug has broad spectrum anti-protozoan activity via inhibition effect in the respiratory chain of parasites including some that cause giardiasis, trichomoniasis, leishmaniasis and toxoplasmosis, water/food-related disease states, as well as malaria (Calvo, Luis Lavandera, Agueeros, \& Irache, 2011). Atovaquone is a highly lipophilic substance with a poor solubility including in gastrointestinal fluids (Dressman \& Reppas, 2000). When administered via tablet or suspension, atovaquone is irregularly absorbed and it shows a very poor bioavailability (Calvo et al., 2011), however, bioavailability is doubled by the simultaneous intake of food ( $23 \%$ in the fasted state and $47 \%$ in the fed state) ("Glaxo Smith Kline," 2010). Comparing bioadhesive nanoparticle formulations, carriers prepared in the presence of cyclodextrin derivatives had calculated relative oral bioavailability of atovaquone that were 1.6-2.2-times higher than for a control suspension (Calvo et al., 2011). The cyclodextrin derivative-containing nanoparticles were thought to slow drug release such that release was better timed relative to the absorption rates in the gut (Calvo et al., 2011).

Another fast-evolving cyclodextrin nanoparticle application relevant to food systems concerns the use of nano-silver: Silver and silverbased compounds have high antimicrobial activity against a wide spectrum of microbes (Kumar, Vemula, Ajayan, \& John, 2008); (Lansdown, 2002) and low toxicity to human cells, however, their commercial use is inhibited by complex multistep preparation methods, high production cost, and low stability/easy oxidation (George, Kuriakose, George, \& Mathew, 2011). Recently, silver nanoparticles were synthesised by reducing silver acetate with a long-chain aliphatic amine and incorporated into $\beta$-cyclodextrin-stabilised silver nanoparticles (George et al., 2011). Aqueous suspensions of these nanoparticles were very stable, and were active against the human pathogens Aspergillus fumigates, Mucor ramosissimus and Chrysosporium species.

Various bioactive flavonoids are effective against free radical-mediated diseases (e.g. atherosclerosis, ischemia, neuronal degeneration, 
cancers, tumors, allergies) thus making them ideal supplemental compounds to prevent the onset of cancer, and possibly effective in reducing oxidative DNA damage of inflammatory bowel disease and colorectal cancer patients (KurzawaZegota, Najafzadeh, Baumgartner, \& Anderson, 2012). However, such applications are limited by low solubility which in turn lowers bioavailability (Pahari, Chakraborty, \& Sengupta, 2011). Cyclodextrin carriers are a possible solution to the latter, whereby their nanostructures are indicative of an encapsulation process involving hydrogen bonding between encapsulated molecules and the cyclodextrin carrier resulting in the formation of the inclusion complex (Pahari et al., 2011).

In another recent cyclodextrin-mediated encapsulation study, their abilities to trap and store gases, including $\mathrm{CO}_{2}$, were investigated (Trotta et al., 2011). Molecular encapsulation of gases in cyclodextrins is best done using $\alpha$-cyclodextrin due to its tight inner cavity, although cyclodextrin "nanosponges" formed by cross linking $\beta$ cyclodextrins can also effectively complex with gases (Cavalli, Trotta, \& Tumiatti, 2006). Crystalline complexes were found to be stable for months at room temperature and gas was released by subsequent dissolution of the crystalline complex in water (Trotta et al., 2011). $\mathrm{CO}_{2}$ was entrapped in $\beta$-cyclodextrin carbonate nanosponges at atmospheric pressure and room temperature, and the entrapment was even strong at $100^{\mathrm{O}} \mathrm{C}$ for $36 \mathrm{~h}$ under vacuum (Trotta et al., 2011). Thus, nanosponges may be useful in food applications such as confections or carbonated frozen food product development.

\subsection{Alginates}

Silymarin, a mixture of mainly three flavonolignans (silybin, silychristin and silydianin), is extracted from the milk thistle. Silymarin has received much attention due to its antioxidant, antidiabetic, hypolipidaemic, anti-inflammatory, cardioprotective, neurotrophic and neuroprotective activities, protein synthesis induction, cell regeneration and its clinical applications in the treatment of various liver diseases, as well as certain types of cancers including skin, breast and prostate (Javed, Kohli, \& Ali, 2011). However, its therapeutic efficacy in humans is limited by its poor solubility and low bioavailability upon oral administration (Woo, Kim, Park, \& Chi, 2007). In a different mode of drug delivery and solubilising vehicles, microscale delivery capsules were recently employed for the delivery of silymarin-containing nanoparticles (El-Sherbiny, Abdel-Mogib, Dawidar, Elsayed, \& Smyth, 2011). The microspheres in question are based on sodium alginate, which were made to encapsulate poly(lactic-co-glycolic acid) (PLGA) nanoparticles (El-Sherbiny et al., 2011). The alginate-PLGA matrices enhanced the dissolution and oral bioavailability of silymarin, and presumably this scheme can be employed for other hydrophobic natural therapeutics (ElSherbiny et al., 2011). Additionally, the particles showed promising biodegradability as well as desirable sustained release profiles for their cargo (El-Sherbiny et al., 2011).

\subsection{Casein}

Casein-based controlled release drug delivery applicability was recently reviewed (Elzoghby et al. 2011). Caseins are good vehicles for bioactives as they are inexpensive, readily available, nontoxic, highly stable, biocompatible, biodegradable, amphiphilic, and they self-assemble into stable micellar structures in aqueous solutions (Elzoghby et al., 2011). Furthermore, caseins' $\mathrm{pH}$-responsive gel swelling behaviour renders them useful for programmable release (Elzoghby et al., 2011). Although the spontaneous binding of hydrophobic compounds to milk caseins and sodium caseinate seems possible, a recent development in modifying casein micelles to minimise the need for harsh temperatures to this end was explored (Chevalier-Lucia, Blayo, GraciaJulia, Picart-Palmade, \& Dumay, 2011). A mechanical and solvent-free process that employs ultra-high pressure homogenisation while limiting/controlling heating effects to preserve heatsensitive biomolecules was studied (ChevalierLucia et al., 2011). Casein micelle size was controllable by modulating temperature, and bioactive ( $\alpha$-tocopherol acetate) binding was correlated to casein micelle size decrease (Chevalier- 
Lucia et al., 2011), thus dosage should be controllable and predictable.

Another recently published nano-casein development concerned camel milk-derived protein. Camel milk has become quite attractive from scientific and industrial points of view, and similar to bovine milk, its $\beta$-caseins are amphiphilic self-assembling proteins that form nano-scale micelles in aqueous solutions (Esmaili et al., 2011). The polyphenolic compound curcumin is isolated from turmeric (Curcuma longa), a member of the ginger family, and has antioxidant (Ruby, Kuttan, Babu, Rajasekharan, \& Kuttan, 1995), anti-inflammatory (Lantz, Chen, Solyom, Jolad, \& Timmermann, 2005) and anti-cancer (Basile et al., 2009; Shi et al., 2006) properties. Curcumin's poor aqueous solubility, degradation and low bioavailability are obstacles for its uses in medicine (Basile et al., 2009). Camel $\beta$-casein micelles' ability to entrap curcumin was investigated, revealing that the micelle-curcumin interactions are mainly hydrophobic, critical to bioactive solubilisation ability, and ultimately its bioavailability and antioxidant activity (Esmaili et al., 2011).

\section{$5 \quad$ Selected recent drug delivery advances employing food-derived materials for non-food medical applications}

Several food-derived materials have been advanced recently with respect to uses in medicine. To improve its clinical applicability, delivery vehicles made of synthetic self-assembling peptide hydrogels as injectable agents for localized curcumin delivery were recently developed (Altunbas, Lee, Rajasekaran, Schneider, \& Pochan, 2011). The resultant application in vitro of the assemblies showed that curcumin's antimedulloblastoma activity was retained without adverse effects on bioactivity, and the rate of curcumin release was controllable and predictable (Altunbas et al., 2011). In another development concerning cancer treatments, a chitosan nanoparticle was recently patented for the delivery of the anti-cancer drug paclitaxel (Nah, J., Jung, T.R., Jang, M. \& Jeong, Y. 2011). A water-soluble chitosan nanoparticle served to en- velop the drug such that the complex was easily re-dispersed in distilled water after being freezedried (Nah, J., Jung, T.R., Jang, M. \& Jeong, Y. 2011). Furthermore, it accumulated in tumour cells better than other anti-cancer drug carriers (Nah, J., Jung, T.R., Jang, M. \& Jeong, Y. 2011). In the area of delivery of bone marrow stem cells, a novel biomimetic and thermosensitive gel scaffold was recently reported that was made from chitosan, nano-hydroxyapatite and collagen (Huang et al., 2011). The resulting gel acted as a biocompatible substrate for the proliferation of rat bone marrow stem cells in vitro, and can enable injection in a minimally invasive manner while providing a biocompatible environment for bone marrow stem cell survival in vivo (Huang et al., 2011).

Palm oil is edible and widely used throughout the world as a food ingredient. Additionally, it was thought to have potential as a raw material in the development of topical drug delivery products (including non-steroidal anti-inflammatory drugs which have low solubility) by facilitating their emulsification into oil/water nano-creams (Abdulkarim et al., 2011). In this regard, a palm nano-cream of around $100 \mathrm{~nm}$ droplets that were stable was recently reported as a drug delivery system (Abdulkarim et al., 2011).

\section{Food therapy}

The therapeutic value of various foods/extracts have been recognised and used for millennia ("UCLA History and Special Collections," 2002). Beyond healthy eating and the consumption of natural remedies, the emergence of 'medical foods' has further minimised and eliminated distinctions between foods that provide sustenance and those that provide healing. A medical food is defined by the FDA as "a food which is formulated to be consumed or administered enterally under the supervision of a physician and which is intended for the specific dietary management of a disease or condition for which distinctive nutritional requirements, based on recognized scientific principles, are established by medical evaluation" ("U.S. Food and Drug Administration," 2009).

For over 50 years, dietary plant sterols have 
been studied for their cholesterol-lowering effects (Lees, Mok, Lees, McCluskey, \& Grundy, 1977), and it was suggested over 30 years ago that plant sterols could be considered a form of dietary treatment in place of a drug for the lowering of cholesterol because plant sterols are naturally present in plant-based foods (Grundy, S.M. \& Mok, H.Y. 1976). By 1995, a margarine product containing proven bioactive plant stanol esters as dietary adjuncts to lower cholesterol had been shown to reduce serum cholesterol in humans (Miettinen, Puska, Gylling, Vanhanen, \& Vartiainen, 1995). Although the example of plant sterol medical use is not directly related to the eventual development of food nanotechnologies, it is an important precursor to the current state of food-for-health endeavours in that it was an early instance of the expansion of food science into modern medical science-based pharmacology (or vice versa). There are very many different medical foods/candidates that are presently the subject of current research. Table 2 outlines recently published examples of the state-of-theart therapeutic food ingredients/extracts.

Due to the explosion of proven nutritional supplements having health benefits (e.g., fish oil, soluble fibre), in addition to medical food developments, it is becoming less clear what is to be considered 'nutraceutical' and what is to be termed 'medical'. Regardless, the delivery platforms presented by food systems for delivering natural and synthesised therapeutic compounds will be critical resources in future preventative and intervention health sciences. Nanotechnology will be at the centre of such developments for reasons discussed below.

\subsection{Targeted delivery}

Advances in bioactive delivery are developing quickly for diverse applications. In the gastrointestinal system, the stability of nanoparticles is influenced by $\mathrm{pH}$, proteases, and the presence of other food compounds (e.g. polysaccharides and lipids) (Wang, Tian, \& Chen, 2011). One general strategy for controlled delivery is the utilisation of enzymes produced by bacteria residing exclusively in the colon as a means of obtaining site specific delivery to this region. The use of se- lected polysaccharides as base materials or coating materials has been employed for this strategy for several years (Macleod, Fell, Collett, Sharma, \& Smith, 1999; Milojevic et al., 1996; Rubinstein \& Radai, 1995).

Two recent food-related nano designs for bioactive/drug delivery were recently published ((Lakshminarayanan, Kesselman, Cohen, Athappan, \& Shimoni, 2011; Wang et al., 2011). Both designs centred on the purposeful employment of nano-carriers that protected their respective bioactive cargos from extreme acidic pH stomach-like conditions, and subsequently released their bioactive cargos in intestine-like conditions. Each design employed the purposeful enzymatic hydrolysis of the carrier materials for accelerating/triggering release (Lakshminarayanan et al., 2011; Wang et al., 2011). Complexes of the $\beta$-glucan curdlan and the bioactive isoflavone genistein were prepared using various methods (Lakshminarayanan et al., 2011). All of the resulting complexes showed high retention of genistein in simulated stomach conditions and subsequently released genistein over prolonged periods of time (Lakshminarayanan et al., 2011). Upon treatment with lyticase, the curdlan-genistein complex release was enhanced by the enzymatic action, thus opening the possibility of release regulation in the digestive tract by the incorporation of lyticase in similar delivery system designs (Lakshminarayanan et al., 2011). The second recent example actually involved the design of microparticles that may provide a new approach for targeted and controlled delivery of nanoencapsulations in the gut that resist nanoparticle aggregation and degradation during storage or in stomach conditions (Wang et al., 2011). Barley protein-based (hordein and glutelin) carrier microparticles were developed for the oral administration of lipophilic bioactive compounds (Wang et al., 2011) such that degradation of the barley protein microparticle bulk matrix in a simulated gastric tract resulted in novel bioactive nano-encapsulated particle formation (Wang et al., 2011). The nano-encapsulated $\beta$-carotene was stable until delivery to a simulated human intestinal tract where subsequent degradation by pancreatic enzymes and steady release of the cargo occurred (Wang et al., 2011). This barley protein-based strategy offers a promising means 
Table 2: Recently published examples of the state-of-the-art in therapeutic food ingredients/extracts for medical applications.

\begin{tabular}{|c|c|c|}
\hline REFERENCE & Active ingredient & Condition / Purpose \\
\hline $\begin{array}{l}\text { (Jackson, Burrell, Gaddie, \& } \\
\text { Richardson, 2011) }\end{array}$ & $\begin{array}{l}\text { Supplementation with the proper } \\
\text { balance of omega- } 3 \text { and omega- } 6 \text { es- } \\
\text { sential fatty acids }\end{array}$ & $\begin{array}{l}\text { Dry eye syndrome improvement, reduce patient symp- } \\
\text { toms }\end{array}$ \\
\hline $\begin{array}{l}\text { (Shell, Bullias, Charuvastra, } \\
\text { May, \& Silver, 2010) }\end{array}$ & $\begin{array}{l}\text { Theramine (Choline Bitartrate, L- } \\
\text { Arginine, L-Histidine, L-Glutamine, } \\
\text { L-Serine, GABA, 5-HTP, Whey Pro- } \\
\text { tein Hydrolysate, Polyphenols, Cin- } \\
\text { namon, Theobromine) }\end{array}$ & $\begin{array}{l}\text { Combine with non-steroidal anti-inflammatory drugs } \\
\text { to allow a reduction in dose used in the treatment of } \\
\text { back pain, thereby reducing side effects }\end{array}$ \\
\hline (Shell et al., 2012) & $\begin{array}{l}\text { Gabadone (amino acid preparation } \\
\text { containing both GABA and 5- } \\
\text { hydroxytryptophan) }\end{array}$ & $\begin{array}{l}\text { Reduce time to fall asleep, decreased sleep latency, } \\
\text { increased the duration of sleep, and improved quality } \\
\text { of sleep }\end{array}$ \\
\hline (Franchi et al., 2012) & $\begin{array}{l}\text { Propolis (resinous product collected } \\
\text { by honey bees) }\end{array}$ & $\begin{array}{l}\text { Cytotoxic (green and red propolis) in human } \\
\text { leukemia cells; also - Antimicrobial, antioxidant, anti- } \\
\text { inflammatory, suppressive effects of dioxin toxicity ac- } \\
\text { tivities }\end{array}$ \\
\hline (Cozzoli et al., 2011) & Taurine (amino acid) & $\begin{array}{l}\text { Combine with } \alpha \text {-methyl-prednisolone (a glucocorti- } \\
\text { coid) to enhance muscular function in dystrophic sub- } \\
\text { jects, thereby allowing a reduction in dose used in } \\
\text { treatments and reducing drug side effects }\end{array}$ \\
\hline (Li et al., 2011) & $\begin{array}{l}\text { Yogurt formulation that used bio- } \\
\text { engineered lactic acid bacteria } \\
\text { strains as a starter culture; the engi- } \\
\text { neered bacteria secrete recombinant } \\
\text { cyanovirin-N (a virucidal protein } \\
\text { from a cyanobacterium) }\end{array}$ & $\begin{array}{l}\text { Candidate compounds in lactic acid bacteria and their } \\
\text { oral administration for mucosal delivery of microbi- } \\
\text { cides; in vivo trials in pigtail macaques showed im- } \\
\text { proved response to viral challenge of rectal tissue }\end{array}$ \\
\hline $\begin{array}{l}\text { (Chaudhary, Sutaria, Huang, } \\
\text { Wang, \& Prabhu, 2011) }\end{array}$ & Calcium and folic acid & $\begin{array}{l}\text { Combine with low dose aspirin; synergistic effects } \\
\text { in reduction of cancer cell viability; chemopreven- } \\
\text { tive agents (aspirin and folic acid) encapsulated } \\
\text { within polymer-based nanoparticles and administered } \\
\text { in combination with calcium have synergistic effect in } \\
\text { inhibition of aberrant crypt foci formation in vivo }\end{array}$ \\
\hline
\end{tabular}

of protecting and directing delivery of bioactives to the lower gut.

\subsection{Targeted drug/bioactive release controlled by disease-state-associated enzymes}

Disease state-associated enzyme-regulated encapsulation is a promising area of health and medicine promoting bioactive delivery that has made some key advances in the past year, potentially opening opportunities for future developments which will be discussed below. Controlledrelease devices have been in commercial use for decades for various advantageous purposes: (i) to maintain drug level in its desired therapeutic range with just a single dose, and (ii) localised delivery to a particular body compartment thereby lowering the systemic drug level, reducing need for follow-up care, preserving medications that are rapidly destroyed by the body, and increasing patient comfort and/or compliance (Kost \& Langer, 2001; Macleod et al., 1999). One strategy for site-specific release has been the sequestration of a given drug in a pro-form (inactive precursor molecules), that can only be freed by enzymatic hydrolysis (Ulijn et al., 2007). The prodrug is designed such that the required hydrolytic specificity is suited to a disease-specific enzyme which thus triggers drug release from a polymeric prodrug carrier. For example, a cancer-specific enzyme secreted by tumor cells can be used to trigger the release of a therapeutic agent to prevent or reduce metastasis (targeted chemotherapy) (Ulijn et al., 2007). Socalled bioresponsive (or biointeractive) materials are encapsulation/carrier components that are stimulated by particular conditions in the target, and this induced state/change in turn causes a change in the carrier properties, resulting in tightly controlled drug release (Ulijn et al., 2007). This scheme is applicable to developing autonomous systems that can detect disease markers and respond to them to repair the 
diseased area (Langer \& Tirrell, 2004). Release rate self-regulation can arise via the use of $\mathrm{pH}-$ sensitive polymers, enzyme-substrate reactions, pH-sensitive drug solubility, competitive binding and metal concentration-dependent hydrolysis (Kost \& Langer, 2001).

Harnessing this selective delivery for devices responding to trigger enzymes, bioresponsive devices were recently constructed to detect microorganisms based on their secretion of polygalacturonic acid degrading enzymes. The hydrogels were composed of alginic acid and polygalacturonic acid, and they housed the red dye Alizarin as an indicator of cargo release. Release was confirmed in test systems in vitro for exogenously added enzymes as well as the pathogens Bacillus subtilis and Yersinia enterocolitica (which secrete pectin degrading enzymes) (Schneider et al., 2011). A similar approach was taken using a cross-linked carboxymethylcellulose and polygalacturonate matrix suitable for the detection of Aspergillus species as they secrete cellulases and pectinases. This approach to polymer-based bioresponse systems could be applied to in situ monitoring for bacteria or fungi in medical applications and food technology (e.g., packaging) (Schneider et al., 2012).

The carbohydrate-based approaches for bioresponse-based delivery used above are certainly promising advances in the field, however, we suggest that one potential drawback of carbohydrates in general is their relative lack of sequence uniqueness, compared to proteins or nucleic acids. With respect to using enzymatic cleavage as the bioresponse basis for controlled release, proteases offer substrate recognition specificity that could greatly improve distinguishing similar types of activities (e.g., pectinase activity can arise from various source organisms, both harmful as well as beneficial gut microflora), and thus carbohydrate-based design can likely only be used for general microorganism detection, but will not be likely to distinguish between pathogens and innocuous species, or pathogenic and non-pathogenic strains of the same species.

\subsection{Food pathogen-responsive delivery of bioactives}

It is known that a biological system often secretes specific enzymes, sometimes with high specificity, in response to certain cellular events such as injury or disease (Powell et al., 1989). If such disease-associated enzymes that are secreted can be co-opted for governing the controlled release of a bioactive cargo, based on specific cellular events or environmental changes, then such a scheme could be highly effective in terms of precise spatial and temporal control (Wen et al., 2011). In our view, a particularly important advance in this area was reported recently for a novel encapsulation class (Wen et al., 2011). Test protein cargos were encapsulated in crosslinked aminopropyl-methacrylamide/acrylamide polymer-based nanocapsules (Wen et al., 2011)). Carriers incorporating plasmin-cleavable, or matrix metalloproteinase-cleavable, crosslinkers were tested at varying target peptide sequence contents. Not only were encapsulated protein cargos released based upon the high specificity of the respective cross-linkers, but their rates of release were proportional to the relative crosslinker contents (Wen et al., 2011). This new class of nanocapsule for controlled, targeted delivery has not been proposed for application in food systems, to the best of our knowledge. We propose that this type of controlled release system could potentially play a powerful role in protecting against, and controlling the populations of, pathogenic organisms in the food chain. Bacteria have evolved multiple mechanisms for the efficient evolution and spread of antimicrobial resistance, and these problems are worsened by the intensive use of antimicrobial agents in both animals and food products (Aarestrup, Wegener, \& Collignon, 2008; Marshall \& Levy, 2011; van der Horst, Schuurmans, Smid, Koenders, \& ter Kuile, 2011; Wang \& Schaffner, 2011). Exposure to low levels of antibiotics which do not thoroughly kill their targets are part of this resistance propagation/transfer (van der Horst et al., 2011), hence it follows that low level use could be rendered safer by improving antibiotic potency and/or efficacy. Of the progress made so far to develop approaches to overcome bacterial resistance to 
penicillins, the use of drug carriers including nanoparticles has been predicted to hold significant promise (Abeylath \& Turos, 2008). Furthermore, action against pathogenic bacteria while avoiding action against non-pathogenic bacteria is important to maintaining host-defence as the alteration in microbiota composition likely creates niches for pathogens to proliferate, including Clostridium difficile-associated disease (Wlodarska \& Finlay, 2010). Similarly for fungal immunity, the association of Candida albicans with gastrointestinal mucosal surfaces has been shown to have large numbers of associated $C$. albicans with the intestinal epithelium of antibiotic-treated mice, but not with that of the control mice that possessed an indigenous wallassociated bacterial flora (Kennedy, Volz, Edwards, \& Yangey, 1987). As a point of discussion we are proposing potential pathogen enzymes for targeted delivery in this area (note that the following are not meant to be a comprehensive review of pathogen-associated proteases).

The principal routes for the entering of $E$. coli O157 into the human food chain is direct or indirect contamination of foods (Harris, Brashears, Garmyn, Brooks, \& Miller, 2012) and waterways (Quilliam, Williams, Avery, Malham, \& Jones, 2011) from environmental sources, and most human E. coli O157 infections are foodborne (Quilliam et al., 2011). The muscle of a healthy animal is essentially sterile, but it can become contaminated during slaughter or processing from the environment, hide, or contact with intestinal tract contents (Harris et al., 2012). Processors have very few interventions for beef trimmings and ground beef, and these products should be recalled if E. coli O157:H7 is detected (Harris et al., 2012), a potentially costly result in terms of both health and money. Sources of enterohemorrhagic E. coli include cattle, sheep, goats, pigs, dogs, chickens, horses, deer, rats, and seagulls, and $\mathrm{O} 157: \mathrm{H} 7$ is found in 30 countries on six continents (Yoon \& Hovde, 2008).

Surface-associated proteolysis is an important feature in migration of eukaryotic cells across tissue barriers, however, the mechanisms of how invasive bacteria spread across tissue barriers of the host is less well-characterised (Suomalainen et al., 2007). Factors that are located on the bacterial surface are secreted into the extracel- lular space and are characteristic of interaction of bacterial pathogens with host cells (Hueck, C.J. 2001). Secreted proteases that damage tissue structures and barriers are obvious virulence factors of bacterial pathogens. The bacterial protease family termed omptins, having an apparently unique catalytic mechanism, are implicated in the virulence of several pathogenic Gram-negative bacteria (Vandeputte-Rutten et al., 2001). Omptin T degrades $\alpha$-helical antimicrobial peptides which could increase bacterial infectivity in the host, and it has narrow proteolytic specificity (Hritonenko \& Stathopoulos, 2007). Another secreted protein, the extracellular serine protease EspP, encoded by the large plasmid of enterohaemorrhagic E. coli O157:H7, could contribute to mucosal haemorrhage observed in patients with haemorrhagic colitis (Brunder, Schmidt, \& Karch, 1997). Importantly, EspP has highly stringent specificity (Brunder et al., 1997) and, along with another secreted protease EhxD, were also shown to be important for adherence to T84 intestinal epithelial cells suggesting a role in tissue interactions (Puttamreddy, 2011). Fungal secreted aspartic proteases (SAPs), encoded by the SAP gene family with ten members, are important factors for C. albicans virulence, and different SAP genes appear to be crucial for mucosal and systemic infections, and are involved in C. albicans adherence, tissue damage and evasion of host immune responses (Hube \& Naglik, 2001). In the case of the foodborne pathogen (human and calves) Salmonella enterica serovar Typhimurium, which causes enterocolitis with diarrhea and polymorphonuclear cell (PMN) influx into the intestinal mucosa, secreted Salmonella invasion protein A (SipA) is critical to bacterial entry into epithelial cells and induction of diarrhea (Lawhon et al., 2011). During infection, the cysteine-aspartic protease caspase-3 hydrolyses SipA at a specific recognition motif in a manner necessary for pathogenicity (Srikanth et al., 2010). In a recent report, the anti-Salmonella activity of a probiotic (Bifidobacterium longum subspp. Infantis) was shown to include the inhibition of Salmonella-induced caspase- 8 and caspase-9 activities in intestinal epithelial cells (Desai, 2011). Furthermore, dissemination of Salmonella-induced extrusion from infected epithelial cells is accompanied by an in- 
flammatory cell death characterised by caspase1 , the inhibition of which significantly decreased extrusion of infected cells (Knodler et al., 2010). Utilisation of such intracellular proteolytic processes for targeting and bioactive/drug delivery may require nanoparticle uptake into cells, technologies reviewed recently for oral vaccines (Wilkhu, McNeil, Kirby, \& Perrie, 2011) as well as nanomedicine approaches against intracellular pathogens (Armstead \& Li, 2011).

Cholera is a severe diarrheal disease caused by specific serogroups of Vibrio cholerae naturally present as free-living organisms in the environment that are pathogenic to humans, but do not persist in a chronic state in humans or animals (Halpern, Gancz, Broza, \& Kashi, 2003). The seasonal appearance of epidemic $V$. cholerae strains and cholera outbreaks has been suggested to depend on ecological associations with aquatic organisms, and hemagglutinin/protease is one of the main secreted proteases of $V$. cholerae usually associated with the stationary phase and starvation in that the secreted hemagglutinin/protease can support free-living survival of the organism in the environment (Halpern et al., 2003). V. cholera enters the body through an oral route of infection with contaminated water or food, and colonises the small intestine where it produces and secretes cholera toxin (Sikora, Zielke, Lawrence, Andrews, \& Sandkvist, 2011). Its type II secretion system is responsible for extracellular secretion of a broad range of proteins including cholera toxin, hemagglutinin/protease, two aminopeptidases, and three serine proteases VesA, VesB, and VesC among others (Sikora et al., 2011). V. cholera secretes its own protease(s) that is/are responsible for cleaving (and thus activation) of cholera toxin (Booth, Boesmanfinkelstein, \& Finkelstein, 1984). VesA, VesB, and VesC were just recently confirmed to have enzymatic activities, and knock-out strains indicated that VesA is the primary protease responsible for processing the A subunit of cholera toxin during in vitro growth of a $V$. cholerae strain (N16961) (Sikora et al., 2011), presumably indicating that VesA has a high degree of specificity. We suggest that nanocarriers containing crosslinking peptides having cleavage sites specific to either hemagglutinin/protease or VesA could be intelligent and effective strategies for the preven- tion and halting of this devastating disease, respectively.

Lastly, Helminth parasites (nematodes, flatworms and cestodes) infect over 1 billion people causing increased morbidity and mortality (Stack, Dalton, \& Robinson, 2011). Intestinal nematode (roundworm) infections, obtained via ingestion of contaminated food, water or soil. (e.g., Ancylostoma caninum, N. americanus, Toxocara canis hookworms, and the cestode Spirometra) involve secreted cathepsin-like proteases (Lecaille, Kaleta, \& Brömme, 2002). It is established that cathepsin B proteases play a key role in the biology of trematodes/flatworms as they are largely expressed by infective parasite stages (Smooker, Jayaraj, Pike, \& Spithill, 2010). Infection with adult forms of the trematode, Paragonimus westermani, mostly in Asia, West Africa, South and Central America, afflict about 20 million people via eating infected crabs or crayfish (Lecaille et al., 2002). While invading the host intestine, several different secreted cysteine proteases have been identified in different maturation stages which participate in a broad range of biological processes such as tissue migration and immune evasion (Lecaille et al., 2002). Recent phylogenetic, biochemical and structural studies indicate that trematode cathepsins exhibit overlapping but distinct substrate specificities (Stack et al., 2011). Harnessing the specificities of such pathogen-associated proteases could prove to be an important future step in the prevention, control and treatment of various foodborne diseases through a new class of food nanotechnology-based controlled release strategies.

\section{Conclusions}

Novel ingredient and packaging functionalities, authentication methods, nutrition enhancement, medical foods and disease prevention/treatment, and safety strategies of the future will likely be driven by advances in nanoscience and technology. Although safety of such advances must always be paramount for their approval and applications to food systems, scientists and regulators would be wise to avoid over-estimating generalised fear among the public, and to treat new 
advances on a basis of individual merit/risk as nanotechnologies cannot reasonably be conceptualised as a single entity. Moreover, benefits of given advances ought to be considered relative to given risks. Harnessing the specificity of pathogen enzymes in designing bioresponsive nano-carriers for on-demand, only as required, dosage-minimised bioactive/drug/germicide delivery in future medical foods or additives, particularly for high risk situations, individuals or outbreaks may be a promising direction in combating pathogenic bacteria, fungi and parasites. Similarly, the application of such strategies may also be useful in combating plant pathogens since both animal and plant cells are targets for type III-dependent protein translocation by bacterial pathogens (Hueck, C.J. 2001). This would be potentially important to improving food security which has been challenged globally by major price spikes for staples such as rice and wheat, partly due to the impact of plant diseases (Dodds \& Rathjen, 2010). Going forward, the purpose and promise of food nanoscience and technology will be central to providing and improving food safety and security, and more generally, to delivering better overall health and wellbeing.

\section{Acknowledgements}

The support of the Natural Sciences and Engineering Research Council of Canada, the Canada Research Chairs Program and Advanced Foods and Materials Canada is gratefully acknowledged.

\section{References}

Aarestrup, F. M., Wegener, H. C., \& Collignon, P. (2008). Resistance in bacteria of the food chain: epidemiology and control strategies. Expert Review of Anti-Infective Therapy, 6(5), 733-750. doi: $\{10.1586 / 14787210.6$. $5.733\}$

Abdulkarim, M., Chitneni, M., Mahdi, E., Yam, M., Faisal, A., Salman, I., ... Noor, A. (2011). Formulation and characterization of palm oil esters based nano-cream for topical delivery of piroxicam. International
Journal of Drug Delivery, 2(4). doi:\{10 . 5138/ijdd.v2i4.54\}

Abeylath, S. C., \& Turos, E. (2008). Drug delivery approaches to overcome bacterial resistance to beta-lactam antibiotics. Expert Opinion on Drug Delivery, 5(9), 931-949. doi: $\{10.1517 / 17425247.5 .9 .931\}$

Altunbas, A., Lee, S. J., Rajasekaran, S. A., Schneider, J. P., \& Pochan, D. J. (2011). Encapsulation of curcumin in self-assembling peptide hydrogels as injectable drug delivery vehicles. Biomaterials, 32(25), 5906-5914. doi:\{10.1016/j . biomaterials.2011.04.069\}

Armstead, A. L., \& Li, B. (2011). Nanomedicine as an emerging approach against intracellular pathogens. International Journal of Nanomedicine, 6, 3281-3293. doi:\{10.2147/ IJN.S27285\}

Augustin, M. A., \& Hemar, Y. (2009). Nanoand micro-structured assemblies for encapsulation of food ingredients. Chemical Society Reviews, 38(4), 902-912. doi:\{10.1039/ b801739p

Basile, V., Ferrari, E., Lazzari, S., Belluti, S., Pignedoli, F., \& Imbriano, C. (2009). Curcumin derivatives: Molecular basis of their anti-cancer activity. Biochemical Pharmacology, 78(10), 1305-1315. doi:\{10.1016/j. bcp.2009.06.105\}

Bhatia, A., Shard, S., Chopra, D., \& Mishra, T. (2011). Chitosan nanoparticles as Carrier of Immunorestoratory plant extract: synthesis, characterization and Immunorestoratory efficacy. International Journal of Drug Delivery, 3(2). doi: $\{10.5138 /$ ijdd.v3i2.234\}

Blasco, C., \& Picó, Y. (2011). Determining nanomaterials in food. Trac-Trends in Analytical Chemistry, 30(1, SI), 84-99. doi: $\{10$. 1016/j.trac.2010.08.010\}

Booth, B., Boesmanfinkelstein, M, \& Finkelstein, R. (1984). Vibrio cholerae hemagglutinin/protease nicks cholera enterotoxin. Infection and Immunity, 45(3), 558-560.

Bouwmeester, H., Dekkers, S., Noordam, M. Y., Hagens, W. I., Bulder, A. S., de Heer, C., ... Sips, A. J. A. M. (2009). Review of health safety aspects of nanotechnologies in food production. Regulatory Toxicology 
and Pharmacology, 53(1), 52-62. doi:\{10. 1016/j.yrtph.2008.10.008\}

Bradley, E. L., Castle, L., \& Chaudhry, Q. (2011). Applications of nanomaterials in food packaging with a consideration of opportunities for developing countries. Trends in Food Science \& Technology, 22(11, SI), 604-610. doi: $\{10.1016 / \mathrm{j}$.tifs . 2011.01.002\}

Brehm-Stecher, B.,F. (2009). Food nanotechnology. The manufacturing confectioner, October, 37-50.

Brunder, W, Schmidt, H, \& Karch, H. (1997). EspP, a novel extracellular serine protease of enterohaemorrhagic Escherichia coli O157:H7 cleaves human coagulation factor V. Molecular Microbiology, 24(4), 767-778. doi: $\{10.1046 /$ j. 1365-2958.1997. 3871751.x\}

Calvo, J., Luis Lavandera, J., Agueeros, M., \& Irache, J. M. (2011). Cyclodextrin/poly(anhydride) nanoparticles as drug carriers for the oral delivery of atovaquone. Biomedical Microdevices, 13(6), 1015-1025. doi:\{10.1007/s10544-011-9571$1\}$

Card, J. W., Jonaitis, T. S., Tafazoli, S., \& Magnuson, B. A. (2011). An appraisal of the published literature on the safety and toxicity of food-related nanomaterials. Critical Reviews in Toxicology, 41(1), 20-49. doi: $\{10.3109 / 10408444.2010 .524636\}$

Cavalli, R., Trotta, F., \& Tumiatti, W. (2006). Cyclodextrin-based nanosponges for drug delivery. Journal of Inclusion Phenomena and Macrocyclic Chemistry, 56(1-2), 209213. 23rd Cyclodextrin Symposium 2005, Nishinomiya, JAPAN, SEP 01-02, 2005. doi:\{10.1007/s10847-006-9085-2\}

Chaudhary, A., Sutaria, D., Huang, Y., Wang, J., \& Prabhu, S. (2011). Chemoprevention of Colon Cancer in a Rat Carcinogenesis Model Using a Novel NanotechnologyBased Combined Treatment System. Cancer Prevention Research, 4 (10), 1655-1664. doi:\{10.1158/1940-6207.CAPR-11-0129\}

Chevalier-Lucia, D., Blayo, C., Gracia-Julia, A., Picart-Palmade, L., \& Dumay, E. (2011). Processing of phosphocasein dispersions by dynamic high pressure: Effects on the dispersion physico-chemical characteristics and the binding of alpha-tocopherol acetate to casein micelles. Innovative Food Science \&6 Emerging Technologies, 12(4), 416-425. doi:\{10.1016/j.ifset.2011.07.007\}

Claonadh, N. ., Casey, A., Lyons, S., Higginbotham, C., Mukherjee, S. G., \& Chambers, G. (2011). Nano-enhanced food contact materials and the in vitro toxicity to human intestinal cells of nano-zno at low dose. Journal of Physics: Conference Series, 304(1), 012038. doi:\{10.1088/1742$6596 / 304 / 1 / 012038\}$

Commission of the European Communities. (2009). Nanosciences and nanotechnologies: An action plan for europe 2005-2009. Second implementation report 2007-2009. Report number: $\mathrm{COM}(2009) 607$ final. December 10, 2011, Retrieved from http : / / eur - lex . europa . eu / LexUriServ / LexUriServ.do? uri=COM:2009:0607:FIN: $\mathrm{EN}: \mathrm{PDF}$

Cozzoli, A., Rolland, J. F., Capogrosso, R. F., Sblendorio, V. T., Longo, V., Simonetti, S., ... De Luca, A. (2011). Evaluation of potential synergistic action of a combined treatment with alpha-methylprednisolone and taurine on the mdx mouse model of Duchenne muscular dystrophy. Neuropathology and Applied Neurobiology, 37(3), 243-256. doi:\{10.1111/j.13652990.2010.01106.x\}

Desai, P. (2011). Molecular interactions of salmonella with the host epithelium in presence of commensals. (Doctoral dissertation). Utah State University.

Dodds, P. N., \& Rathjen, J. P. (2010). Plant immunity: towards an integrated view of plant-pathogen interactions. Nature Reviews Genetics, 11(8), 539-548. doi: $\{10$. $1038 / \operatorname{nrg} 2812\}$

Dressman, J., \& Reppas, C. (2000). In vitroin vivo correlations for lipophilic, poorly water-soluble drugs. European Journal of Pharmaceutical Sciences, 11(2), S73-S80. Meeting on Frontiers in Biopharmacy, St Remy Provence, France, Jun 15-17, 2000. doi:\{10.1016/S0928-0987(00)00181-0\}

Duncan, T. V. (2011b). Applications of nanotechnology in food packaging and food 
safety: Barrier materials, antimicrobials and sensors. Journal of Colloid and Interface Science, 363(1), 1-24. doi: \{10.1016/j. jcis.2011.07.017\}

Duncan, T. V. (2011a). The communication challenges presented by nanofoods. Nature Nanotechnology, 6(11), 683-688. doi:\{10 . 1038/nnano.2011.193\}

El-Sherbiny, I. M., Abdel-Mogib, M., Dawidar, A.-A. M., Elsayed, A., \& Smyth, H. D. C. (2011). Biodegradable pHresponsive alginate-poly (lactic-co-glycolic acid) nano/micro hydrogel matrices for oral delivery of silymarin. Carbohydrate Polymers, 83(3), 1345-1354. doi:\{10.1016/ j.carbpol.2010.09.055\}

Elzoghby, A. O., El-Fotoh, W. S. A., \& Elgindy, N. A. (2011). Casein-based formulations as promising controlled release drug delivery systems. Journal of Controlled Release, 153(3), 206-216. doi:\{10.1016/j.jconrel. 2011.02.010\}

Esmaili, M., Ghaffari, S. M., Moosavi-Movahedi, Z., Atri, M. S., Sharifizadeh, A., Farhadi, M., ... Moosavi-Movahedi, A. A. (2011). Beta casein-micelle as a nano vehicle for solubility enhancement of curcumin; food industry application. Lwt-Food Science and Technology, 44(10), 2166-2172. doi: $\{10$. 1016/j.lwt.2011.05.023\}

Fathi, M., Mozafari, M. R., \& Mohebbi, M. (2012). Nanoencapsulation of food ingredients using lipid based delivery systems. Trends in Food Science \& Technology, 23(1), 13-27. doi:\{10.1016/j.tifs.2011.08. $003\}$

Feynman, R. (1960). There's plenty of room at the bottom. Caltech engineering and science, 23(5), 22-36.

Flendrig, L.M. and Marshman, C.E. and Velikov, K.P. \& Winter, I. (2009). Calcium fortified food product and additive. United States of America. Patent number US 20090238947 (Assigned to Conopco, Inc. on May 13, 2008).

Franchi, G. C., Jr., Moraes, C. S., Toreti, V. C., Daugsch, A., Nowill, A. E., \& Park, Y. K. (2012). Comparison of Effects of the Ethanolic Extracts of Brazilian Propolis on Human Leukemic Cells As Assessed with the MTT Assay. Evidence-Based Complementary And Alternative Medicine. doi: $\{10.1155 / 2012 / 918956\}$

George, C., Kuriakose, S., George, S., \& Mathew, T. (2011). Antifungal activity of silver nanoparticle-encapsulated betacyclodextrin against human opportunistic pathogens. Supramolecular Chemistry, 23(8), 593-597. doi:\{10.1080/10610278. $2011.575471\}$

Gimzewski, J., \& Vesna, V. (2003). The nanoneme syndrome: Blurring of fact and fiction in the construction of a new science. Technoetic arts, 1(1), 7-24. doi:\{10.1386/ tear.1.1.7/0\}

Glaxo Smith Kline. (2010). Summary of Product Characteristics: Wellvone $750 \mathrm{mg} / 5 \mathrm{ml}$ oral suspension. December 10, 2011, Retrieved from http://www.medicines.org.uk/EMC/ medicine/777/SPC/Wellvone\%20750mg\% 205ml\%20oral\%20suspension/\#FORM

Grundy, S.M. \& Mok, H.Y. (1976). Effects of low dose phytosterols on cholesterol absorption in man. In H. Greten. (Eds). In Lipoprotein metabolism (pp. 112-118). Berlin, Germany: Springer-Verlag.

Halpern, M, Gancz, H, Broza, M, \& Kashi, Y. (2003). Vibrio cholerae hemagglutinin/protease degrades chironomid egg masses. Applied and Environmental Microbiology, 69(7), 4200-4204. doi:\{10.1128/ AEM.69.7.4200-4204.2003\}

Harris, D., Brashears, M. M., Garmyn, A. J., Brooks, J. C., \& Miller, M. F. (2012). Microbiological and organoleptic characteristics of beef trim and ground beef treated with acetic acid, lactic acid, acidified sodium chlorite, or sterile water in a simulated commercial processing environment to reduce Escherichia coli O157:H7 and Salmonella. Meat Science, 90(3), 783788. doi: $\{10.1016 /$ j.meatsci.2011.11.014\}

Health Canada. (2011a). Policy statement on Health Canada's working definition for nanomaterial (version 2). December 10, 2011, Retrieved from http://www.hc-sc. gc.ca/sr-sr/pubs/nano/pol-eng.php

Health Canada. (2011b). Summary of comments received on the interim policy statement on Health Canada's working definition for 
nanomaterials - March to August 2010. December 10, 2011, Retrieved from http:// www.hc-sc.gc.ca/sr-sr/pubs/nano/sumres-eng.php

Hritonenko, V., \& Stathopoulos, C. (2007). Omptin proteins: an expanding family of outer membrane proteases in Gram-negative Enterobacteriaceae. Molecular Membrane Biology, 24(5-6), 395-406. doi: $\{10.1080 / 09687680701443822\}$

Huang, Z., Yu, B., Feng, Q., Li, S., Chen, Y., \& Luo, L. (2011). In situ-forming chitosan/nano-hydroxyapatite/collagen gel for the delivery of bone marrow mesenchymal stem cells. Carbohydrate Polymers, 85(1), 261-267. doi: $\{10.1016 / \mathrm{j}$. carbpol . 2011.02.029\}

Hube, B., \& Naglik, J. (2001). Candida albicans proteinases: Resolving the mystery of a gene family. Microbiology, 148(8), 19972005.

Hueck, C.J. (2001). Type III protein secretion systems in bacterial pathogens of animals and plants. Microbiology and molecular biology reviews, 62(2), 379-433.

Jackson, M., Burrell, K., Gaddie, I., \& Richardson, S. (2011). Efficacy of a new prescription-only medical food supplement in alleviating signs and symptoms of dry eye, with or without concomitant cyclosporine A. Clinical ophthalmology, 5, 1201-1206. doi:\{10.2147/OPTH.S22647\}

Javed, S., Kohli, K., \& Ali, M. (2011). Reassessing Bioavailability of Silymarin. Alternative Medicine Review, 16(3), 239-249.

Kanwar, J. R., Long, B. M., \& Kanwar, R. K. (2011). The Use of Cyclodextrins Nanoparticles for Oral Delivery. Current Medicinal Chemistry, 18(14), 2079-2085. doi:\{10. 2174/092986711795656243\}

Kennedy, M. J., Volz, P. A., Edwards, C. A., \& Yangey, R. J. (1987). Mechanisms of association of Candida albicans with intestinal mucosa. Journal of Medical Microbiology, 24 (4), 333-341. doi:\{10.1099/00222615-244-333\}. eprint: http://jmm.sgmjournals . org/content/24/4/333.full.pdf +html

Kim, C., Kim, C., Cho, Y., Choi, S., \& Choi, A. (2011). Nanoemulsion and nanoparticle containing plant essential oil and method of production thereof. Europe. Patent number EP 2173194 (Assigned to Korea Food Research Institute on September 21, 2011). Retrieved from http://www. freepatentsonline.com/EP2173194B1.html

Knodler, L. A., Vallance, B. A., Celli, J., Winfree, S., Hansen, B., Montero, M., \& SteeleMortimer, O. (2010). Dissemination of invasive Salmonella via bacterial-induced extrusion of mucosal epithelia. Proceedings of the National Academy of Sciences of the United States of America, 107(41), 1773317738. doi: $\{10.1073 /$ pnas.1006098107\}

Kost, J, \& Langer, R. (2001). Responsive polymeric delivery systems. Advanced Drug Delivery Reviews, 46(1-3), 125-148. doi: $\{10$. 1016/S0169-409X(00)00136-8\}

Kumar, A., Vemula, P. K., Ajayan, P. M., \& John, G. (2008). Silver-nanoparticleembedded antimicrobial paints based on vegetable oil. Nature Materials, 7(3), 236241. doi: $\{10.1038 /$ nmat2099\}

Kurkov, S. V., Ukhatskaya, E. V., \& Loftsson, T. (2011). Drug/cyclodextrin: beyond inclusion complexation. Journal of Inclusion Phenomena and Macrocyclic Chemistry, 69(3-4, SI), 297-301. 1st European Cyclodextrin Conference, Aalborg, Denmark, Oct 11-13, 2009. doi:\{10.1007/s10847-0109756-x\}

Kurzawa-Zegota, M., Najafzadeh, M., Baumgartner, A., \& Anderson, D. (2012). The protective effect of the flavonoids on foodmutagen-induced DNA damage in peripheral blood lymphocytes from colon cancer patients. Food and Chemical Toxicology, 50 (2), 124-129. doi: \{10.1016/j.fct. $2011.08 .020\}$

Lagaron, J. M., \& Lopez-Rubio, A. (2011). Nanotechnology for bioplastics: opportunities, challenges and strategies. Trends in Food Science \& Technology, 22(11, SI), 611-617. doi: $\{10.1016 /$ j.tifs.2011.01.007\}

Lakkis, J.M. \& García, A.J.M. (2011). Calcium fortified food product and additive. Clarke, Modet \& Co. Microcapsules containing salts for food products. Europe. Patent number EP 2292102 (Assigned to Lipofoods S. L. on March 9, 2011). 
Lakshminarayanan, R., Kesselman, E., Cohen, R., Athappan, P., \& Shimoni, E. (2011). Curdlan complexes as a potential food-grade delivery system: Genistein case study. Therapeutic delivery, 2(2), 181-192. doi: $\{10.4155 /$ tde.10.114\}

Langer, R, \& Tirrell, D. (2004). Designing materials for biology and medicine. $\mathrm{Na}$ ture, 428(6982), 487-492. doi:\{10.1038/ nature02388\}

Lansdown, A. (2002). Silver I: Its antibacterial properties and mechanism of action. Journal of wound care, 11(4), 125-130.

Lantz, R., Chen, G., Solyom, A., Jolad, S., \& Timmermann, B. (2005). The effect of turmeric extracts on inflammatory mediator production. Phytomedicine, 12(6-7), 445-452. doi:\{10.1016/j.phymed.2003.12. $011\}$

Lawhon, S. D., Khare, S., Rossetti, C. A., Everts, R. E., Galindo, C. L., Luciano, S. A., .. Adams, L. G. (2011). Role of SPI1 Secreted Effectors in Acute Bovine Response to Salmonella enterica Serovar Typhimurium: A Systems Biology Analysis Approach. Plos One, 6(11). doi:\{10.1371/ journal.pone.0026869\}

Lecaille, F, Kaleta, J, \& Brömme, D. (2002). Human and parasitic papain-like cysteine proteases: Their role in physiology and pathology and recent developments in inhibitor design. Chemical Reviews, 102(12), 44594488. doi: $\{10.1021 / \operatorname{cr} 0101656\}$

Lees, A., Mok, H., Lees, R., McCluskey, M., \& Grundy, S. (1977). Plant sterols as cholesterol-lowering agents: Clinical trials in patients with hypercholesterolemia and studies of sterol balance. Atherosclerosis, 28(3), 325-338. doi:\{10.1016/00219150(77)90180-0\}

Li, M., Patton, D. L., Cosgrove-Sweeney, Y., Ratner, D., Rohan, L. C., Cole, A. M., .. Ramratnam, B. (2011). Incorporation of the HIV-1 Microbicide Cyanovirin$\mathrm{N}$ in a Food Product. Jaids-Journal of Acquired Immune Deficiency Syndromes, 58(4), 379-384. doi: $\{10$. 1097 / QAI . 0b013e31823643fe\}

Lin, N., Huang, J., Chang, P. R., Anderson, D. P., \& Yu, J. (2011a). Preparation,
Modification, and Application of Starch Nanocrystals in Nanomaterials: A Review. Journal Of Nanomaterials. doi:\{10.1155/ $2011 / 573687\}$

Lin, Q. B., Li, B., Song, H., \& Wu, H. J. (2011b). Determination of silver in nano-plastic food packaging by microwave digestion coupled with inductively coupled plasma atomic emission spectrometry or inductively coupled plasma mass spectrometry. Food Additives and Contaminants Part A-chemistry Analysis Control Exposure \& Risk Assessment, 28(8), 1123-1128. doi: $\{10.1080 /$ 19440049.2011.580013\}

Lindel, D. (2011). The food and beverage industry in Germany 2011/2012. W. MacDougall. (Eds). Berlin: Germany Trade and Invest.

Lu, Q., Li, D.-C., \& Jiang, J.-G. (2011). Preparation of a Tea Polyphenol Nanoliposome System and Its Physicochemical Properties. Journal of Agricultural and Food Chemistry, 59(24), 13004-13011. doi:\{10. 1021/jf203194w\}

Macleod, G., Fell, J., Collett, J., Sharma, H., \& Smith, A. (1999). Selective drug delivery to the colon using pectin : chitosan : hydroxypropyl methylcellulose film coated tablets. International Journal of Pharmaceutics, 187(2), 251-257. doi:\{10.1016/ S0378-5173(99)00196-9\}

Magnuson, B. A., \& Bouwmeester, H. (2011). Toxicology of nanomaterials in food, In Nanotechnology in the agri-food sector (pp. 171-190). Wiley-VCH Verlag GmbH \& Co. KGaA. doi:10.1002/9783527634798. ch10

Magnuson, B. A., Jonaitis, T. S., \& Card, J. W. (2011). A Brief Review of the Occurrence, Use, and Safety of Food-Related Nanomaterials. Journal of Food Science, 76(6), R126-R133. doi: $\{10.1111 /$ j. 1750 - 3841 . 2011.02170.x\}

Makhlof, A., Tozuka, Y., \& Takeuchi, H. (2011). Design and evaluation of novel $\mathrm{pH}$-sensitive chitosan nanoparticles for oral insulin delivery. European Journal of Pharmaceutical Sciences, 42(5), 445-451. doi: $\{10.1016 / \mathrm{j}$. ejps.2010.12.007\} 
Marshall, B. M., \& Levy, S. B. (2011). Food Animals and Antimicrobials: Impacts on $\mathrm{Hu}-$ man Health. Clinical Microbiology Reviews, 24 (4), 718+. doi:\{10.1128/CMR.00002$11\}$

Miettinen, T., Puska, P, Gylling, H, Vanhanen, H, \& Vartiainen, E. (1995). Reduction Of Serum-Cholesterol with SitostanolEster Margarine in a Mildly Hypercholesterolemic Population. New England Journal of Medicine, 333(20), 1308-1312. doi:\{10.1056/NEJM199511163332002\}

Milojevic, S, Newton, J., Cummings, J., Gibson, G., Botham, R., Ring, S., ... Allwood, C. (1996). Amylose as a coating for drug delivery to the colon: Preparation and in vitro evaluation using 5-aminosalicylic acid pellets. Journal of Controlled Release, 38(1), 75-84. doi: $\{10.1016 / 0168-3659(95) 00112-$ $3\}$

Mishra, B., Patel, B. B., \& Tiwari, S. (2010). Colloidal nanocarriers: a review on formulation technology, types and applications toward targeted drug delivery. NananomedicineNanotechnology Biology and Medicine, 6(1), 9-24. doi:\{10.1016/j.nano.2009.04. $008\}$

Morris, V. J. (2011). Emerging roles of engineered nanomaterials in the food industry. Trends in Biotechnology, 29(10), 509-516. doi:\{10.1016/j.tibtech.2011.04.010\}

Murugeshu, A., Astete, C., Leonardi, C., Morgan, T., \& Sabliov, C. M. (2011). Chitosan/PLGA particles for controlled release of alpha-tocopherol in the GI tract via oral administration. Nanomedicine, 6(9), 1513-1528. doi: $\{10.2217 / N N M .11 .44\}$

Nah, J., Jung, T.R., Jang, M. \& Jeong, Y. (2011). Water soluble chitosan nanoparticle for delivering an anticancer agent and preparing method thereof. United States of America. Patent number US 7883723B2 (Assigned to Nah, J., Jung, T.R. \& Jang, M. on February 8, 2011).

National Nanotechnology Institute. (2011). Nanotechnology timeline, December 08. Retrieved from http:// www. nano.gov/ timeline

Neethirajan, S., \& Jayas, D. S. (2011). Nanotechnology for the Food and Bioprocessing In- dustries. Food and Bioprocess Technology, 4(1), 39-47. doi:\{10. 1007 / s11947-0100328-2\}

Pahari, B., Chakraborty, S., \& Sengupta, P. K. (2011). Encapsulation of 3-hydroxyflavone in gamma-cyclodextrin nanocavities: Excited state proton transfer fluorescence and molecular docking studies. Journal of Molecular Structure, 1006(1-3), 483-488. doi: $\{10.1016 /$ j.molstruc.2011.09.055

Plapied, L., Duhem, N., des Rieux, A., \& Préat, V. (2011). Fate of polymeric nanocarriers for oral drug delivery. Current Opinion In Colloid $\&$ Interface Science, 16(3), 228 237. doi: $\{10.1016 /$ j.cocis.2010.12.005\}

Powell, J., Clozel, J., Muller, R., Kuhn, H, Hefti, F, Hosang, M, \& Baumgartner, H. (1989). Inhibitors of Angiotensin-Converting Enzyme Prevent Myointimal Proliferation After Vascular Injury. Science, 245(4914), 186-188. doi: $\{10.1126 /$ science.2526370\}

Prabaharan, M. (2011). Prospective of guar gum and its derivatives as controlled drug delivery systems. International Journal Of Biological Macromolecules, 49(2), 117-124. doi:\{10.1016/j.ijbiomac.2011.04.022\}

Project on Emerging Nanotechnologies. (2011). Inventories, December 9, 2011. Retrieved from http : / / www . nanotechproject.org / inventories

Puttamreddy, S. (2011). Genetic analysis of Escherichia coli o157:h7 biofilm formation. (Doctoral dissertation). Iowa State University.

PytlikZillig, L. M., \& Tomkins, A. J. (2011). Public Engagement for Informing Science and Technology Policy: What Do We Know, What Do We Need to Know, and How Will We Get There? Review of Policy Research, 28(2), 197-217. doi: $\{10.1111 /$ j. 1541-1338.2011.00489.x\}

Quilliam, R. S., Williams, A. P., Avery, L. M., Malham, S. K., \& Jones, D. L. (2011). Unearthing human pathogens at the agricultural-environment interface: A review of current methods for the detection of Escherichia coli O157 in freshwater ecosystems. Agriculture Ecosystems \& Environment, 140(3-4), 354-360. doi:\{10. $1016 /$ j.agee.2011.01.019\} 
Rashidi, L., \& Khosravi-Darani, K. (2011). The Applications of Nanotechnology in Food Industry. Critical Reviews in Food Science and Nutrition, 51(8), 723-730. doi:\{10 . 1080/10408391003785417\}

Ravindranath, S. P., Wang, Y., \& Irudayaraj, J. (2011). SERS driven cross-platform based multiplex pathogen detection. Sensors and Actuators B-Chemical, 152(2), 183-190. doi: $\{10.1016 /$ j.snb.2010.12.005\}

Roco, M. (2011). The Long View of Nanotechnology Development: The National Nanotechnology Initiative at 10 Years. In M. C. Roco, M. C. Hersam, C. A. Mirkin \& M. C. Roco. (Eds). In Nanotechnology research directions for societal needs in 2020 (Vol. 1, pp. 1-28). Science Policy Reports. Springer Netherlands. doi:\{10.1007/97894-007-1168-6_1\}

Rubinstein, A., \& Radai, R. (1995). In vitro and in vivo analysis of colon specificity of calcium pectinate formulations. European journal of pharmaceutics and biopharmaceutics, 41(5), 291-295.

Ruby, A., Kuttan, G, Babu, K., Rajasekharan, K., \& Kuttan, R. (1995). Anti-tumour and antioxidant activity of natural curcuminoids. Cancer Letters, 94(1), 79-83. doi: $\{10.1016 / 0304-3835(95) 03827-J\}$

Schneider, K. P., Wehrschuetz-Sigl, E., Eichhorn, S. J., Hasmann, A., Flock, T., Kaufmann, F., .. Guebitz, G. M. (2012). Bioresponsive systems based on crosslinked polysaccharide hydrogels. Process Biochemistry, 47(2), 305-311. doi:\{10.1016/j . procbio. 2011.11.013\}

Schneider, K. P., Rollett, A., Wehrschuetz-Sigl, E., Hasmann, A., Zankel, A., Muehlebach, A., ... Guebitz, G. M. (2011). Bioresponsive systems based on polygalacturonate containing hydrogels. Enzyme and Microbial Technology, 48(4-5), 312-318. doi: $\{10$. 1016/j.enzmictec.2011.01.003\}

Scientific Committee on Emerging and Newly Identified Health Risks (SCENIHR). (2010). Scientific basis for the definition of the term "nanomaterial". Report number: ND-AS-09-004-EN-N. Retrieved from http : / / ec . europa . eu / health / scientific_committees / emerging / docs / scenihr_o_032.pdf

Sessa, M., Tsao, R., Liu, R., Ferrari, G., \& Donsi, F. (2011). Evaluation of the Stability and Antioxidant Activity of Nanoencapsulated Resveratrol during in Vitro Digestion. Journal of Agricultural and Food Chemistry, 59(23), 12352-12360. doi:\{10. 1021/jf2031346\}

Shell, W., Bullias, D., Charuvastra, E., May, L. A., \& Silver, D. S. (2010). A Randomized, Placebo-Controlled Trial of an Amino Acid Preparation on Timing and Quality of Sleep. American Journal of Therapeutics, 17(2), 133-139. doi:\{10.1097/MJT. 0b013e31819e9eab\}

Shell, W. E., Charuvastra, E. H., DeWood, M. A., May, L. A., Bullias, D. H., \& Silver, D. S. (2012). A Double-Blind Controlled Trial of a Single Dose Naproxen and an Amino Acid Medical Food Theramine for the Treatment of Low Back Pain. American Journal of Therapeutics, 19(2), 108-114. doi: $\{10.1097 /$ MJT.0b013e3181f4b297\}

Shi, M., Cai, Q., Yao, L., Mao, Y., Ming, Y., \& Ouyang, G. (2006). Antiproliferation and apoptosis induced by curcumin in human ovarian cancer cells. Cell Biology International, 30(3), 221-226. doi: $\{10.1016 / \mathrm{j}$. cellbi.2005.10.024\}

Sikora, A. E., Zielke, R. A., Lawrence, D. A., Andrews, P. C., \& Sandkvist, M. (2011). Proteomic Analysis of the Vibrio cholerae Type II Secretome Reveals New Proteins, Including Three Related Serine Proteases. Journal of Biological Chemistry, 286(19), 16555-16566. doi:\{10. 1074 / jbc. M110. $211078\}$

Smolander, M., \& Chaudhry, Q. (2010). Nanotechnologies in food packaging. In Q. Chaudhry, L. Castle \& R. Watkins (Ed.), Nanotechnologies in food (pp. 86-101). Cambridge: The Royal Society of Chemistry. doi: $\{10.1039 / 9781847559883-00086\}$

Smooker, P. M., Jayaraj, R., Pike, R. N., \& Spithill, T. W. (2010). Cathepsin B proteases of flukes: the key to facilitating parasite control? Trends in Parasitology, 26(10), 506-514. doi:\{10.1016/j.pt.2010.06.001\} 
Sozer, N., \& Kokini, J. L. (2009). Nanotechnology and its applications in the food sector. Trends in Biotechnology, 27(2), 82-89. doi: $\{10.1016 /$ j.tibtech.2008.10.010\}

Srikanth, C. V., Wall, D. M., MaldonadoContreras, A., Shi, H. N., Zhou, D., Demma, Z., ... McCormick, B. A. (2010). Salmonella Pathogenesis and Processing of Secreted Effectors by Caspase-3. Science, 330 (6002), 390-393. doi: $\{10.1126 /$ science. $1194598\}$

Srinivas, P. R., Philbert, M., Vu, T. Q., Huang, Q., Kokini, J. L., Saos, E., ... Ross, S. A. (2010). Nanotechnology Research: Applications in Nutritional Sciences. Journal of Nutrition, 140(1), 119-124. doi:\{10.3945/ jn.109.115048\}

Stack, C., Dalton, J. P., \& Robinson, M. W. (2011). The Phylogeny, Structure and Function of Trematode Cysteine Proteases, with Particular Emphasis on the fasciola hepatica cathepsin L family. In M. W. Robinson \& J. P. Dalton (Eds.), Cysteine Proteases of Pathogenic Organisms (Vol. 712, pp. 116-135). Advances in Experimental Medicine and Biology. Springer US. doi: $\left\{10.1007 / 978-1-4419-8414-2 \_8\right\}$

Suomalainen, M., Haiko, J., Kukkonen, M., Korhonen, T., Lähteenmäki, K., Virkola, R., .. Ramu, P. (2007). Using Every Trick in the Book: The Pla Surface Protease of Yersinia pestis. In R. D. Perry \& J. D. Fetherston (Eds.), The Genus Yersinia (Vol. 603, pp. 268-278). Advances in Experimental Medicine and Biology. Springer New York. doi:\{10.1007/978-0-387-721248_24\}

Sweeney, A.E. \& Seal, S. (2008). Developing a viable knowledge base in nanoscale science and engineering. In A. E. Sweeney \& S. Seal (Eds). In Nanoscale science and engineering education (pp. 1-35). Stevenson Ranch, CA, USA: American Scientific.

Taniguchi, N. (1974). On the basic concept of nanotechnology. In Proceedings of the international conference of product engineering Tokyo Part 2 (18-23). Japan Society of Precision Engineering, Tokyo, Japan.

Teow, Y., Asharani, P. V., Hande, M. P., \& Valiyaveettil, S. (2011). Health impact and safety of engineered nanomaterials. Chemical Communications, 47(25), 7025-7038. doi: $\{10.1039 /$ c0cc05271j\}

The European Commission. (2011). Commission recommendation of 18 October 2011 on the definition of nanomaterial text with EEA relevance. Report number: Official Journal L 275. December 10, 2011, Retrieved from http : / / eur - lex . europa . eu / LexUriServ / LexUriServ .do? uri=OJ :L:2011:275:0038: 01:EN:HTML

The European Food Safety Authority. (2011). Outcome of the public consultation on the draft scientific opinion on guidance on risk assessment concerning potential risks arising from applications of nanoscience and nanotechnologies to food and feed. Report number: 2011:126. December 10, 2011, Retrieved from http://www.efsa.europa.eu/ en/supporting/doc/126e.pdf

The International Organization for Standardization. (2011). Nanotechnologies - nanomaterial risk evaluation. Report number: ISO/TR 13121:2011. December 10, 2011, Retrieved from http://www.iso.org/iso/ home.htm

Trotta, F., Cavalli, R., Martina, K., Biasizzo, M., Vitillo, J., Bordiga, S., ... Ansari, K. (2011). Cyclodextrin nanosponges as effective gas carriers. Journal of Inclusion Phenomena and Macrocyclic Chemistry, 71(12), 189-194. doi: $\{10.1007 /$ s10847 - 011 9926-5\}

UCLA History and Special Collections. (2002). Use of spices as medicines. December 7, 2011, Retrieved from http:// unitproj. library . ucla . edu / biomed / spice / index . cfm $?$ spicefilename $=$ SpicesAsMeds . txt \& itemsuppress $=$ yes\& displayswitch $=0$

Ulijn, R. V., Bibi, N., Jayawarna, V., Thornton, P. D., Todd, S. J., Mart, R. J., ... Gough, J. E. (2007). Bioresponsive hydrogels. $M a-$ terials Today, 10(4), 40-48. doi:\{10.1016/ S1369-7021(07)70049-4\}

U.S. Food and Drug Administration. (2009). Medical Foods. December 7, 2011, Retrieved from http://www.fda.gov/Food/ FoodSafety / Product-SpecificInformation/ MedicalFoods/default.htm 
U.S. Food and Drug Administration. (2011a). Considering whether an FDA-regulated product involves the application of nanotechnology - Guidance for industry. Report number: ucm257698. December 10, 2011, Retrieved from http:// www.fda . gov / RegulatoryInformation / Guidances / ucm257698.htm

U.S. Food and Drug Administration. (2011b). Draft guidance for industry: Dietary supplements: New dietary ingredient notifications and related issues. Report number: ucm257563. December 10, 2011, Retrieved from http://www.fda.gov/Food/ GuidanceComplianceRegulatoryInformation/ GuidanceDocuments

DietarySupplements/ucm257563.htm

van Putten, E. G., Akbulut, D., Bertolotti, J., Vos, W. L., Lagendijk, A., \& Mosk, A. P. (2011). Scattering Lens Resolves Sub-100 nm Structures with Visible Light. Physical Review Letters, 106(19). doi:\{10.1103/ PhysRevLett.106.193905\}

van der Horst, M. A., Schuurmans, J. M., Smid, M. C., Koenders, B. B., \& ter Kuile, B. H. (2011). De Novo Acquisition of Resistance to Three Antibiotics by Escherichia coli. Microbial Drug Resistance, 17(2), 141-147. doi: $\{10.1089 / \mathrm{mdr} .2010 .0101\}$

Vandeputte-Rutten, L, Kramer, R., Kroon, J, Dekker, N, Egmond, M., \& Gros, P. (2001). Crystal structure of the outer membrane protease OmpT from Escherichia coli suggests a novel catalytic site. Embo Journal, 20(18), 5033-5039. doi:\{10.1093/emboj/ 20.18.5033\}

Wang, H. H., \& Schaffner, D. W. (2011). Antibiotic Resistance: How Much Do We Know and Where Do We Go from Here? Applied and Environmental Microbiology, 77(20), 7093-7095. doi:\{10.1128/AEM.06565-11\}

Wang, R., Tian, Z., \& Chen, L. (2011). Nanoencapsulations liberated from barley protein microparticles for oral delivery of bioactive compounds. International Journal of Pharmaceutics, 406(1-2), 153-162. doi:\{10.1016/j.ijpharm.2010.12.039\}

Wen, J., Anderson, S. M., Du, J., Yan, M., Wang, J., Shen, M., ... Segura, T. (2011). Controlled Protein Delivery Based on Enzyme-
Responsive Nanocapsules. Advanced Materials, 23(39), 4549+. doi:\{10.1002/adma. 201101771\}

Wijnhoven, S. W. P., Peijnenburg, W. J. G. M., Herberts, C. A., Hagens, W. I., Oomen, A. G., Heugens, E. H. W., ... Geertsma, R. E. (2009). Nano-silver - a review of available data and knowledge gaps in human and environmental risk assessment. Nanotoxicology, 3(2), 109-U78. doi:\{10.1080/ $17435390902725914\}$

Wilkhu, J., McNeil, S., Kirby, D., \& Perrie, Y. (2011). Formulation design considerations for oral vaccines. Therapeutic delivery, 2(9), 1141-1164. doi:\{10.4155/tde.11. $82\}$

Wlodarska, M., \& Finlay, B. B. (2010). Host immune response to antibiotic perturbation of the microbiota. Mucosal Immunology, 3(2), 100-103. doi: $\{10.1038 / \mathrm{mi} .2009 .135\}$

Woo, J. S., Kim, T.-S., Park, J.-H., \& Chi, S.-C. (2007). Formulation and biopharmaceutical evaluation of silymarin using SMEDDS. Archives of Pharmacal Research, 30(1), 82-89. doi:\{10.1007/BF02977782\}

Yan, L., Chang, P. R., Zheng, P., \& Ma, X. (2012). Characterization of magnetic guar gum-grafted carbon nanotubes and the adsorption of the dyes. Carbohydrate Polymers, 87(3), 1919-1924. doi: $\{10.1016 / \mathrm{j}$. carbpol.2011.09.086\}

Yan, L., Chang, P. R., \& Zheng, P. (2011). Preparation and characterization of starchgrafted multiwall carbon nanotube composites. Carbohydrate Polymers, 84(4), 1378-1383. doi:\{10.1016/j. carbpol. 2011. $01.042\}$

Yoon, J. W., \& Hovde, C. J. (2008). All blood, No stool: enterohemorrhagic Escherichia coli O157 : H7 infection. Journal of Veterinary Science, 9(3), 219-231. doi:\{10.4142/jvs. 2008.9.3.219\} 